\title{
Reflection in a High-Performance Sport Coach Education Program: A Foucauldian Analysis of Coach Developers
}

\section{Lauren Downham and Christopher Cushion}

\section{Abstract}

Reflection is a contested but taken-for-granted concept whose meaning shifts to accommodate the interpretation and interests of those using the term. Subsequently, there is limited understanding of the concept. The purpose of this paper was to consider critically the discursive complexities of reflection and their articulation through coach developers' practice. Data were collected from a National High-Performance coach education program. Coach developers responsible for one-to-one support $(n=8)$ and on-program support $(n=3)$ participated in the research. Semi-structured interviews were conducted with coach developers and participant observations were undertaken of a coach developer forum and program workshops $(n=9)$. Foucault's concepts; power, discourse and discipline were used to examine data with critical depth. Analysis explored 'Discourse of Reflection', 'Discipline, Power and Reflection' and 'Coach Developers: Confession, 'Empowerment' and Reflection'. Humanistic ideas constructed a discourse of reflection that was mobilized through coach confession. Coach developer efforts to be 'critical' and 'learner centered' were embroiled with intrinsic and subtle relations of power as 'empowering' intent exacerbated rather than ameliorated its exercise. This paper makes visible a different destabilized and problematized version of reflection, thus introducing an awkwardness into the fabric of our experiences of reflection.

Key Words: Reflective Practice, Sport Coaching, Foucault, Power 


\section{Introduction}

Reflection and reflective practice have become conspicuous parts of coach education and the terms ensconced in the vocabulary of coach developers (Cushion, 2016; Cushion, Griffiths \& Armour, 2018). To be 'reflective' is seen as an essential part of coach learning (e.g. Cassidy, Jones \& Potrac, 2009; Gallimore, Gilbert \& Nater, 2014; Gilbert \& Trudel, 2001; 2006) and an examination of literature pertaining to coaching and the reflective practitioner reveals the way in which the concept of reflection has often taken center stage (Cushion, 2016). Reflection and reflective practice are positioned as essential tools for coach developers looking to enhance professional development (e.g. Culver \& Trudel, 2006), link theory and practice (e.g. Douglas \& Carless, 2008; Irwin, Hanton \& Kerwin, 2004), promote critical thinking (e.g. Knowles, et al., 2001; Knowles et al., 2006; Taylor, Werthner, Culver \& Callary, 2015), lead to self-awareness and understanding (e.g. Cassidy et al., 2009; Gilbert \& Côté, 2013), empower coaches and athletes (e.g. Kidman 2005, Richards, Mascarenhas \& Collins, 2009), and promote learning and enhanced practice (e.g. Cushion, Ford \& Williams, 2012; Cropley, Miles \& Peel, 2012; Gilbert \& Trudel, 2001; Irwin et al., 2004).

Indeed, it is clear that coach developers should encourage coaches to question their values, beliefs and ideas, and engage with a process to develop their knowledge and make sense of their experiences (Cushion 2016; Fendler, 2003). However, as Cushion (2016) argues, despite the significant work privileging reflective practice in coaching, little interrogates these notions critically; instead reflection and reflective practice are presented uncritically and accepted enthusiastically as 'good' for coaching and coaches. Research has tended to sidestep these wider socio-cultural issues and instead focused on 'applying' or developing reflection (e.g. Knowles et al., 2001; Taylor et al., 2015; Trudel, Culver, \& Werthner, 2013; inter-alia), or providing 
expositions of a preferred theoretical approach (e.g. Cassidy et al., 2009; Cushion, 2006; Gilbert \& Trudel, 2006; Trudel et al., 2013). This perspective is reinforced by Cropley and Hanton (2011), who argue that coaching has preached the positives of reflection, or 'jumped on the bandwagon' (Cropley et al., 2012, p. 2) without fully appreciating the issues and problems facing coach developers aiming to cultivate reflective practice. Specifically, relations of power and their role in constructing the meaning of reflection and influencing how coach developer's enable reflection has been overlooked in existing work. Indeed, while guided reflection can offer much as an empowering and emancipatory process (Johns, 1999), no research considers if coaching culture, specifically coach development, accommodates this process or whether, as Cushion (2016) argues, reflection slips into a mode of reinforcing existing practice and power relations. et al. (2018) argue that until very recently coach developers have remained largely absent from coach education research; a body of work which is understandably coachcentric. This means that the role of coach developers and their practice and influence have been taken-for-granted, assumed, or simply rendered invisible. Indeed, while reflection has been a central feature in coach education research (e.g. Cassidy, Potrac \& McKenzie, 2006; Knowles, Borrie \& Telfer, 2005; Nelson \& Cushion, 2006) coach developers' understanding, application, and overall contribution to this in practice has yet to be examined. This is problematic because coach developers, like coaches (Denison, Mills and Konoval, 2015), are enmeshed within relations of powerknowledge. Indeed, they have a significant role in supporting reflection to achieve its empowering intent through educating coaches to recognize and understand powerknowledge relations and their consequences. 
Therefore, the purpose of this paper was to consider critically the discursive complexities of reflection and reflective practice and their articulation with and through coach developer practice. Importantly, reflection and reflective practice are not benign or neutral concepts. Thus, through a Foucauldian lens, we aimed to consider how power operated and provide a critical analysis of the complexity of reflection with coach developers in a high-performance coach development program. The significance of the work, then, was as Foucault (1996) asserted "to reveal relations of power...to put them back into the hands of those who exercise them" (p.144). Therefore, we undertook a critical analysis of the complexity of coaching and reflective practices to enable the unintended consequences of well-intended practices to be uncovered (Fendler, 2003) because "power does not just prevent things happening, it also produces effects' (Foucault, 1980, p. 59).

\section{Approaches in Coach Development}

The design and delivery of coach education and the work of coach developers, including the use of reflection, will have an approach informed by underpinning and sometimes implicit beliefs about learning (Cushion et al., 2018). One such approach influencing coaching currently is a humanistic approach, based on humanistic psychology (cf. Rogers, 1983) (Usher \& Edwards, 2005). The rationale underpinning the educational process and the role of the coach developer in a humanistic approach is 'learner-centered'. That is, where the learner is self-motivated and self-directed, exercising individual agency and making their own authentic choices about selfdevelopment and self-realization (Usher \& Edwards, 1994; 2005). In this approach, the coach developer is a guide and looks to make an 'empowering' contribution developing autonomous learners to develop their subjectivity and identity. A key tenet of this approach is it purports to be 'power-free' or attempts to democratize power (Foucault, 
102 or no power over others, or choice about how it is exercised (Brookfield, 2009). This

103 means that coaching and coach education is seen as a neutral, benign space where

104 reflection is a desirable activity to develop 'better' coaches who are 'empowered' or

105 made 'autonomous' (Cushion, 2016; Cushion \& Jones, 2014; Denison et al., 2015).

106 However, coaching has dynamic, complex, and diffused networks of power relations

107 where reflection is in fact embedded in a persistent and resilient culture (Cushion, 2016;

108 Cushion \& Jones, 2014).

\section{Mobilizing Foucault}

110 Drawing on Foucault's work is useful as it helps us recognize more subtle forms of

111 power, "as a productive network which runs through the whole social body" (Foucault,

112 1980, p. 119), where individuals who make up the social body are made by, and are the

113 primary vehicles of, power (Orlie, 1997). Indeed, Foucault (1998) understood power as

114 relations between people therefore omnipresent. Power is not an institution, a certain

115 strength or a possession, 'it is the name that one attributes to a complex strategical

116 situation in a particular society' (Foucault, 1998, p. 93). Foucault (1980) states that

117 'relations of power cannot themselves be established, exercised, consolidated or

118 implemented without the production, accumulation, circulation and functioning of a

119 discourse' (p. 93), which is a rule-governed, socio-historically situated language.

120 Discourse can refer to the written and unwritten rules that guide social practices and

121 help to produce and regulate the production of statements that correspondingly control

122 what can be understood and perceived, but at the same time, act to obscure (Foucault,

123 1972). In this sense, reflection can be considered a discourse that is embedded in and

124 related to other coaching discourses (e.g. coach education, coaching philosophy,

125 coaching practice) (Cushion, 2016). Foucault (1975) connected power and knowledge, 
articulating that "power has a need for a certain form of knowledge...that the exercise

127 of power creates and causes to emerge new objects of knowledge...and, conversely,

128 knowledge constantly induces effects of power...It is not possible for power to be

129 exercised without knowledge, it is impossible for knowledge not to engender power"

130 (Faubion, 2002, p. xv).

131 Foucault used the category of discipline to extend the perception of how modern

132 power operates to carefully construct and form subjectivities (Cole, Giardina, \& 133 Andrews, 2004) through surveillance and self-surveillance (Foucault, 1977). Foucault

134 (1977) linked (self) surveillance to panopticism, a concept based on Jeremy Bentham's

135 architectural figure the panopticon. According to Foucault (1977), the panoptic

136 mechanism arranges spatial unities through structures designed to induce a state of

137 conscious and permanent visibility. Importantly, this visibility is unverifiable; that is,

138 panopticism ensures that the subject does not know if or when they are being observed

139 (or listened to). Together, this surveillance ensures the automatic functioning of power.

140 Foucault (1977) identified these structures across institutions such as prisons, schools,

141 hospitals and factories. Indeed, all people, including coaches, are subject to surveillance

142 through a normalizing (self) gaze and are under real or imagined pressure to conform

143 to societal norms relating to their behavior (Denison, et al., 2015). Importantly, this

144 gaze has progressed from just observing behavior to include an interest in what people

145 think as well as what they do (Rolfe \& Gardner, 2006).

$146 \quad$ Foucault (1977) identified three disciplinary mechanisms that operate through

147 this gaze: hierarchical judgement, spatial organization and examination. That is, bodies

148 and minds are never just trained, but are subjected to normative judgement or what

149 Foucault (1977) calls dividing practices. These practices produce and exclude

150 individuals, for example a coach developer may label a coach in line with the 
conventions of the prevailing discourse thus classifying, disciplining, and normalizing

152 through social processes that they have little direct control over (Markula \& Pringle, 153 2006). In coaching (Mills \& Denison, 2018) and other related practice fields (Cotton, 154 2001; Rolfe \& Gardner, 2006), an increasingly unnoticed operation of power that 155 supports dividing practices is confession that occurs in the presence of an authority, 156 such as a coach developer, who has the ability to judge, punish, forgive, console and 157 reconcile the confessor (Foucault, 1998). Mills and Denison (2018) have identified 158 athlete confession in coaching that acted to address 'abnormality' and so reinforce and 159 normalize whatever was 'true'. However, research is yet to consider how such 160 disciplinary mechanisms may play out in coach education, specifically between coach 161 and coach developer. Together, disciplinary matrices create 'docile bodies' controlled and regulated

163 where 'training' extends capacity and usefulness. While in one sense productive and 164 perhaps desirable, docility does not necessarily mean optimal performance or achieving 165 one's potential (Denison, 2010). Docility can limit the development of skills and 166 qualities, such as problem solving, decision making, and understanding capacities and 167 capabilities (e.g. Denison, 2007; Gearity \& Mills, 2013; Mills \& Denison, 2013). 168 Indeed, docility can include the mind; as Cushion (2016) argued, concepts such as 169 reflection can construct ways of thinking, as well as doing. Put simply, coach 170 development that determines what coaches think, the techniques they use, and their 171 efficiency is likely to reproduce existing ideas to be productive within established 172 structures. This is not to say that some discourses and practices in coaching have not 173 changed, indeed, 'new' ideas are continually emerging and deemed possible, but this 174 notion is often illusory as change must be within what is deemed acceptable (Mills \& 175 Denison, 2018). That is, discourses are produced and accumulated, they circulate and 
176 function, thus establishing, consolidating, and implementing relations of power

177 (Foucault, 1980). In other words, power, through an overarching disciplinary

178 framework remains, and coaching carries an incomplete and naïve understanding of

179 this. Indeed, practitioners are often coerced into conforming to the dominant culture

180 and find it difficult, if not impossible, to 'stand outside it and see it for what it is' (Johns,

181 1999, p. 241). This 'movement of power and the restrictions this places on coaches'

182 inventiveness can be problematic within a high-performance sport context where

183 innovativeness is paramount for advancing athletes' performances' (Mills \& Denison,

1842018 , p. 298). Innovation has been considered an outcome of reflection and reflective

185 practice and a mark of coach development (cf. Trudel, Rodrique \& Gilbert, 2016).

186 Therefore, coach development, in this context, needs to support coaches to achieve

187 more than productivity as a docile body. Indeed, there are calls for coaches to be able

188 to problematize their practice (e.g. Konoval, Denison \& Mills, 2018) and coach

189 developers can play a central role in challenging existing discourse and practices,

190 surfacing contradictions in practice, and shining a light beyond the status quo to disturb

191 disciplinary practices, docility, and relations of power (Johns, 1999; Mills \& Denison, 192 2018).

193 Indeed, while disciplinary practices are often taken-for-granted in coaching

194 (Denison, Mills and Jones, 2013) and have been associated with reflection, reflective 195 practice, and confession (Cushion, 2016; Fejes, 2008; Fendler, 2003; Mills \& Denison,

196 2018), no research has considered the role and influence of coach developers in this

197 process. As a result, there remains no research that discusses critically or considers

198 reflection and reflective practice as, for example, practices of 'subjectivity formation'

199 or as a disciplinary practice, nor connects this to the practices of coach developers. To

200 explore the extent of these issues, we draw on Foucault's concepts to explain how 
reflection has been operationalized and understood by coach developers in a high-

202 performance coach development program.

\section{Methodology}

\section{Background and context}

205 Under investigation was a high-performance coach education program delivered by a

206 National Sports Organization (NSO) in the United Kingdom. The program was 207 designed to be 'beyond' the Sport Governing Body (SGB) coach development. That is, 208 'more advanced', offering unique opportunities and experiences for coaches from 209 multiple sports and the highest performance level. The NSO is a large national 210 organization with a presence in coach education and is organized in terms of multi211 departments, intra-organizational relationships, and distributed work arrangements. 212 The program, spread over a three-year period, involved residential workshops, one-to213 one coach development sessions, and in-situ visits to the coaches by coach developers.

214 The research reported here forms part of a larger twenty-four-month ethnographic study 215 that analyzed the delivery and impact of the coach education program on developing 216 reflection and reflective practice. This included the perspectives of the coach 217 developers, the coach learners, and the NSO in which the program was undertaken. 218 This paper focuses specifically on the coach developers and reports findings on their 219 understanding and supporting of reflection and reflective practice with their coaches (n $220=11$ ) from the program. Eight coach developers were assigned to provide one-to-one 221 coaching and mentoring support. These coach developers met their coach(es) every 222 four-to-six weeks for a one-to-one session and provided distance support via email or 223 video-call in the interim. Three coach developers were responsible for on-program 224 support, and observed the coaches on residential workshops, and provided feedback. 


\section{Participants}

226 The eight coach developers responsible for one-to-one support had executive coaching 227 accreditation. The NSO selected three coach developers for each high-performance 228 sport coach, who then assigned one coach developer to work with for the duration of 229 the program. The participants were selected using criterion-based purposeful sampling 230 (Patton, 2002). Criteria considered their experiences and involvement in the program, 231 which were conducive with achieving the aims of the research. Following Cushion et 232 al. (2018), each participant is described individually (identified by pseudonyms) in 233 Table 1.0, incorporating words from their own initial narratives; this allows each to 234 "highlight critical episodes and events...providing insight into their understanding" 235 (Webster \& Mertova, 2007, p.69) of their experience and approach to reflection, 236 coaching and coach development. This detail shows that reflection had been 237 conceptualized in lots of different ways and that coach developers operated without a 238 consistent underpinning.

\section{Participant Details: One-to-One Coach Developers}

'I wanet an elite athlete... I went to the Olympics, I graduated with a sports
science degree, as an elite athlete I also did my PhD'. Janet's work with
the NSO started '10 years ago...it has been a natural progression
delivering projects and the one-to-one mentoring role'. Janet identified
reflection as 'using your own brain to learn from the experiences that
you've been through'.
A former high-performance athlete who has worked in the training and
development sector of a corporate business for 16 years. Georgia
explained 'I have been coaching now for 20 years and I am also a
coaching supervisor, so I support coach developers. Georgia described
reflection as 'that ability to think about practice...it is like with the plan-
do-review cycle... you are able to get insight that influences how you do
it next time...you are not only learning about the situation but you are
reflecting on and refining your beliefs and how you see the world'.


Rebecca An organization development consultant who specializes in organizational behavior and leadership. Rebecca has 20 years experience and is the managing director of her own business. Previously, she held a chief executive position in business. She has a master's degree and coaching certification. Rebecca explained that 'reflective practice is about raising self-awareness by noticing what I thought, felt and the sensations I experienced in relation to myself, the other and the situation and that for me is how I would define it [reflective practice]'.

Emma Has spent '20 years working on leadership development particularly starting with leadership assessment [e.g.] psychometric assessment using psychometric tools, personality tools' with businesses and individuals...to identify their high potential pool, MD [Managing Director] successors, senior functional head successors [and] future CEO's [Chief Executives]'. Emma has executive coaching accreditation and a master's degree. Emma described an example of a reflective practice conversation she might have with a high-performance coach after a championships 'to get people [coaches] to stop and think, so "what have I learnt about myself and who I am as a head coach, or a leader of coaches, and what can I do with that learning, what have I learnt about my program, what have I learnt about my athletes and my other coaches and how I can use that information going forward'.

Isla 'My background is sports science, MPhil, exercise physiology...I was an international sport coach [and] an international performer'. Isla has had roles within sport-related publicly funded organizations and the private sector, 'eventually I became a full-time consultant, trained up got the qualification in business coaching and since then have done business coaching, leadership development, but have always kept sport clients...I was passionate about coaching coaches... and then qualifications came along and it became an industry'. Isla described reflection as 'bringing into consciousness what's going on and attempting to make sense of it historically, in the moment for the future'.

Sophie Has been the managing director of her own company, which specializes in executive leadership coaching, for over 10 years. Sophie works with both private and public sector businesses and organizations offering executive coaching. She has a master's degree and published work focused on executive coaching. Sophie described reflection as the process of 'shifting someone and getting them off the transactional, because they often give you the performance, but if nothing is changing and everything is stuck in this groove you can't get better... "can we just get off this" and go way below takes people courage'. 


Poppy been CEO for a business that specializes in 'change' through
executive coaching and leadership development for 25 years. She has
worked with the NSO for 11 years; 'I see my role as supporting these
coaches on their learning and development journey... as trying to help
bring some thread or glue to the program through the
dialogue...primarily focused on the learning goals that we both identify
and that immerge through the program'. Poppy went on to talk about her
role in relation to influencing how reflection is perceived and practiced
'If I can try to instill that it is about the reflection process and not getting
to the end it may allow coaches to focus on the 'in the moment', it doesn't
come to a natural end'.
Has been the director of a business which specializes in executive
coaching, coach supervision and training for 14 years. Ahead of this,
Claire ran her own independent consultancy business for 20 years. She
has a master's degree and is an accredited coaching supervisor. She
explained her view on reflection through an example 'I would start with
'so tell me where you have got to withyour thinking about this [coaching
issue], because clearly you have been thinking about it'. There's your
reflection'.

Table 1.0. Participant Details; One-to-One Coach Developers

The three on-program coach developers were all male and worked for the NSO.

241 Similarly, these participants are now described individually (identified by pseudonyms)

242 in Table 2.0 incorporating words from their own narratives.

\section{Participant Details: On-Program Coach Developers}

Was a high-performance athlete and is currently a sport coach in a high-
performance youth context. 'I manage the coach development team, I set
the strategy for our plans about how we go about developing coaches for
the system to support the vision for medal winning success'. Will
described reflection as 'the ability to critically appraise activity or action
with a view to learning from that critical thinking and thought process in
order to apply that learning in the future context. I think it [reflection]
can then be delivered pre, during, post activity, I think the skill is knowing
how to use those reflections to adapt practice and shape future practice.
During data collection, Will moved from a role involving in-situ coach
support visits and workshop delivery to this strategic position.
Was responsible for organizing and coordinating the high-performance
coach education workshops. During data collection Tim also provided
Tim


some in-situ support to the coaches, he led tasks at workshops and provided coaches with individual written feedback. Tim believes that 'some people aren't maximizing the potential they've got in making the most of their experiences...it's important to understand...what's gone well or not and why and how they learn from it in the future'. In building on this, Tim described reflection as 'looking back at what happened, and at your part in it... what happened and why... and what did I do or didn't do, and can I learn from it'.

Alan Participated in the early stages of data collection. Alan led residential workshops, supported coaches in-situ and provided feedback. He expressed that it is important 'to try and work out the best way to get effective reflective practice for different individuals' and described reflection as 'as looking back to plan forwards'.

243 Table 2.0: Participant Details; On-Program Coach Developers

\section{Research Design and Procedures}

245 On receiving institutional ethical approval, data were collected during the two-year 246 ethnography using participant observation and interviewing (Hammersley \& Atkinson, 247 2007). To capture how the coach developers understood and supported reflection and 248 reflective practice, data collection had three phases:

249 Phase 1: Participant observation of coach education workshops ran throughout data 250 collection. This included observations of nine coach education residential workshops, 251 each running for two-to-three days and a half-day coach developer forum. The coach 252 developer forum focused on identifying key themes relating to 'topics', 'successes' and 253 'challenges' experienced in the one-to-one sessions. The fifth residential workshop was 254 also attended by the one-to-one coach developers; they supported group discussions 255 with coaches during on-program tasks. During each observation, lecture style sessions, 256 group work, and practical activities were observed. Fieldnotes were made throughout 257 these observations and included descriptive detail and key information such as the 258 location, who was present, what social interaction occurred, and what activities took 259 place (Bryman, 2016; Cushion, 2014). 
Phase 2: Individual semi-structured interviews were conducted with one-to-one (n

$261=6)$ and on-program $(n=3)$ coach developers from month 9 to 12 . These interviews 262 were conducted face-to-face $(n=4)$, by video-call $(n=3)$ and phone call $(n=2)$ and 263 ranged from 41 minutes to 75 minutes; the average was 56 minutes. Following Smith 264 and Sparkes (2017), the interviews invited coach developers to tell stories about their 265 practice. This enabled them to explain the meanings they constructed from their 266 experiences and describe their perspectives and behaviors in relation to reflection; in 267 their one-to-one sessions, their individual methods or tools for reflection, their 268 perceptions of what reflection meant and how their individual context influenced their 269 reflective practice support. This focused on understanding what the coach developers 270 did and why, and how they constructed their work, role, and reflection.

271 Phase 3: Individual interviews conducted face-to-face $(n=1)$ and by video $(n=6)$

272 with one-to-one coach developers were conducted in month 21 and ranged from 30 to 27360 minutes. By this stage, two one-to-one coach developers had left the program and 274 one did not respond to the invite for a second interview. These interviews revisited data 275 from phase one and two, with a view to considering how reflection was understood at 276 this later stage and whether this had changed or remained same. This meant one-to-one 277 coach developers had an opportunity to consider their previous comments and offer 278 further insight (Smith \& Sparkes, 2017). Taken together, the coach developers 279 contributed four times to the data collected.

\section{Data Analysis}

281 Data analysis included inductive (data-driven) and deductive (theory-driven) 282 approaches, supported by the application of social theory, to identify both manifest 283 (explicit) and latent (underlying) meanings (Clarke \& Braun, 2017). The interviews 284 were transcribed verbatim and the workshops as full-field notes. Initially, a form of 
thematic analysis was used to identify patterns of meaning in the data (Clarke \& Braun,

286 2017). Within this, initial coding reduced the data, then the codes were collated based 287 on their similarity. For example, initial codes identified through coach developer 288 interview data included: 'open-minded', 'flexible', 'coach-led', 'coach-centered', 'non289 directive' and 'supportive'. These were then grouped as 'coach-centered'. Examples 290 from the raw data were stored alongside the collated codes for future reference; for 291 instance, 'coach centered' data examples included: 'it is about them and their 292 learning...the sessions are about them and how the sessions can help them and shape 293 their learning, it is not something I want to do for them or direct them towards'. In line 294 with Braun and Clarke (2013), comparisons between the participants and conceptual 295 and empirical reflection literature, in both coaching and more broadly in teaching and 296 adult learning, were then explored. This form of thematic analysis provided what Braun 297 and Clarke (2006) described as 'a rich and detailed, yet complex, account of data' (p. 298 78). Clarke and Braun (2017) explained that thematic analysis can be applied across a 299 range of theoretical perspectives. In this research, deductive analysis applied Foucault's 300 concepts. This situated data within a theoretical framework enabling a move from 301 concrete description to abstraction while retaining a constant grounding in the data (cf. 302 Cushion et al., 2018). Together, this iterative process of meaning making worked to 303 explain data with critical depth. In following Clarke and Braun's (2017) final stage of 304 analysis, this is now presented through a discussion of three themes; 'Discourse of 305 Reflection, 'Discipline, Power and Reflection' and 'Coach Developers: Confession, 306 'Empowerment' and Reflection'.

\section{Analysis and Discussion}

\section{Discourse of Reflection}


For Foucault (1972), reality is constituted through discourse, a rule-governed, socio-

310 historically situated language "practices that systematically form the objects of which

311 they speak" (p.49) that "position subjectivities" (p. 182). A dominant discourse

312 comprises a particular language and a distinctive view where some things are regarded

313 as inherently more important than others (Brookfield 2009). In this case, reflection and

314 reflective practices were seen as an important and essential part of the coach education

315 program, a 'golden thread' running throughout, and a specific aspect that the coach

316 developers were expected to lead. As a result, a discourse of reflection was constructed

317 that comprised of a particular language of and for reflection, as well as distinctive and

318 dominant views about reflection. Such views positioned reflection as being about

319 facilitating learning through the discussing and solving of coaching 'problems':

\section{Interviews:}

Janet: I would say firstly it's about you which is fairly obvious...I come very much from a view where I would like to help you solve your problems by asking questions by maybe sharing experiences but, sometimes telling, but not often, so it is about using you in the real world to develop you rather than anything else.

Poppy: It is usually related to a goal and or learning objective, but there can be random things come up, that you know, I never know what it is that someone wants to talk to me about.

In addition, reflection and, therefore, learning were grounded in using the knowledge that the coaches already had. Importantly, reflection on the program was a process that involved making coaches' knowledge visible for scrutiny and assessment. In this example, the coach developer asks coaches for topics that will inform group reflection time ('white space').

\section{Fieldnotes}

Residential Workshop: 
The coach developer refers to the flip chart paper, he asks for topics the coaches wish to discuss during their 'white space' time later today.

Tim: "This time it is your time to drive the real content of it, and what we are really trying to do always is to protect some of that time for you to hold the floor and get whatever it is that you want to get out of the time in the room....an opportunity to bring to life some of your topics... we have got 37 minutes, so we are going to have seven minutes writing down anything you could talk about and then half an hour within which you can pick one or two and then go into as much detail as you want and then we can address the rest over the next couple of days...I am going to write them up on this flip-chart paper".

Coach - Harry: "A thought around the project, I am fascinated to know whether program do share male - female ways of operating, how integrated it is and has anyone tried it? Linked in with that, is there is a massive push with the questioning approach in coaching, and balance of that over the 'tell'...I am curious as to how that is in other sports right now and what people's thoughts and feelings are towards that".

...The group select gender to discuss further. They begin to share their thoughts - the focus is on what has worked for them and their experiences which are put forward alongside sport specific examples.

Furthermore, these data illustrate a typical discursive pattern, where the discourse included value judgements made by coach developers about the 'nature', and quality of, reflection. In addition, something of the normalizing aspect of reflection discourse is revealed, where, for example, reflection was about 'you', and the importance of seeing the 'value' in doing reflection. Indeed, within the program, all the coach developers privileged reflection and reflective practice and presented it uncritically and enthusiastically, as 'good' for their coaches and high-performance coaching (cf. Cushion, 2016).

A discourse also includes rules for judging what are good or bad, acceptable or inappropriate contributions and procedures. This meant that, to enable reflection, a series of 'good' and 'acceptable' pedagogic practices were espoused and practiced by 
the coach developers. These included one-to-one reflection sessions to facilitate

376 'learning conversations', individual and group discussion and feedback in allocated

377 'white space' or 'reflection time' on residential workshops.

378 Importantly, these practices were underpinned by humanistic ideas of learner-

379 centeredness, empowerment, and self-direction:

Interviews:

Janet: It's about you.

Isla: Let's talk about what's going on for you.

Emma: It's about learning to learn...[and] managing yourself... Sometimes, awareness is change, it can be transformative.

Poppy: I never know what someone wants to talk to me about.

These ideas not only produced concrete coach developer practices, but were also a discursive production of meaning and objects on the program - reflective thought and 390 reflective practice - that construed reflection as desirable and also constituted 391 subjectivities. These discursive formations created the conditions of possibility for the 392 shaping of coaches' behavior by the discourse of reflection. In other words, the 393 discourse shaped and fostered coaches to become the 'reflective coach', who was 394 'empowered' by reflecting continuously to improve their practice and themselves (cf. 395 Cotton, 2001; Cushion, 2016; Usher \& Edwards, 2005). As the examples below show, 396 this resulted in coaches who internalized this reflection discourse and therefore construed reflection as both a desirable and entirely positive activity: and where you feel you are now. 
it...she just challenges and gets you thinking and thinking about listening and how you ask questions, I would say that would be biggest influence.

These coach data show the strong sense of recitation and repetition of the humanistic reflection discourse where the coaches believed that 'you' were taking control of 'your' learning. On the surface then, reflection construed in this positive and 'learnercentered' way appeared to avoid the reproduction of power, what Foucault (1977) describes as the "temporary inversion of power relations" (p. 26). But the discourse served to constitute the coaches as subjects. That is, they accepted the legitimacy of coach developer practices and the truth of the meanings they invoked - that they were 'empowered'. However, Foucault states that power produces discourses and knowledges - the couplet power-knowledge indicates that "power produces knowledge" and that "power and knowledge directly imply one another" (p. 27). Hence, coach educator practices around reflection remained subject to power-knowledge formations and gave certain subjectivities significance. Indeed, according to Foucault, (1980) "relations of power cannot themselves be established without the production, accumulation, circulation and functioning of discourse" (p.93). Hence, reflection and the coach developer's practice were conditional upon, and a condition of, the exercise of power. Practices that were considered participatory and power free were, in fact, subject to subtle forms of power - disciplinary power.

\section{Discipline, Power and Reflection}

Foucault's (1977) model for the functioning of modern power is the Panopticon, where everyone is "caught up in a power situation of which they are themselves the bearers" (p. 201), and the category of discipline extends notions of how power operates (Cole et al., 2004). Discipline refers to a technology (a technique as well as knowledge) that shapes and produces individuals through techniques of surveillance and self- 
surveillance that reverberate through social and individual bodies (Foucault, 1977).

432 Disciplinary matrices create 'docile bodies' and minds "that may be subjected, used, 433 transformed and improved" (Foucault, 1977, p. 136). Importantly, in this case what 434 counted as improved was shaped and supervised by the coach developers and the 435 organization. The implication being that coaching 'expertise' becomes not a matter of 436 what the coach can do or knows (c.f. Gilbert \& Côté, 2013), but through reflection an 437 articulation of the way coaches see, think and even feel, and the socialized meaning 438 ascribed to this (Gilbert, 2001). Thus, the 'effective' coach, who by 'reflection' 439 develops their abilities, is a function of the production of institutionalized and 440 discursive bodies. Crucially, this was in contrast to the program's intentions that 441 focused on supporting critical thinking and novel coaching practices. Thus, attempts to 442 develop coaches 'differently' are implemented without understanding how disciplinary 443 power is present, active, and often unseen in all places and all of the time (Denison et 444 al., 2015).

445 Foucault's (1977) disciplinary mechanisms; gaze, hierarchical judgement, 446 spatial organization, and examination, were in operation on the program, and therefore 447 reflection can be considered usefully as techniques of disciplinary power. First, the 448 coach developers, as discussed earlier, utilized a range of 'pedagogical practices' within 449 the program that was highly organized in terms of time and space, and particularly for 450 the coaches to engage with reflection. These dividing practices produced various coach 451 groups for facilitated 'reflective practice' where division for example by 'experience', 452 'coachability', or 'type of learner' had productive power to demarcate, circulate, and 453 differentiate. Dividing practices are forces of normalization that produce and exclude, 454 as the coach developers were able to utilize "a normalizing gaze, a surveillance that 455 makes it possible to qualify and classify" (Foucault, 1977, p. 184). 
These practices also subjected the coaches to surveillance and self-surveillance,

457 fashioning a panoptical discourse of control. For example, the discussion circle was

458 reified on the program as democratic and learner centred and used frequently for

459 facilitated reflection. However, this was a situation in which scrutiny and surveillance

460 by the coach developers and by other coaches was dramatically heightened; a situation

461 in which actions were carefully watched by the "judges of normality" (Foucualt, 1977,

462 p. 304). These judges (coach developers) were positioned hierarchically as experts and

463 monitored the extent to which the coaches were participating and 'reflecting' in an

464 appropriate manner. Coach educators, as judges of normality, overtly established the

465 criteria for participation to operationalize the norm's rule of conduct. For the coaches,

466 there was the unspoken knowledge that a lack of participation or saying the 'wrong

467 thing' would be evident. Importantly, such normalizing gaze was not recognized; as

468 Mills and Denison (2018) describe, it operated innocently and discreetly, through

469 reflection on the program. The examples below demonstrate that coaches were

470 classified as a certain type of learner or subject. The coaches in their efforts to be a

471 'reflective practitioner' were examined and measured against an idealized 'normal

472 reflective coach'. This norm held that there was a particular type (e.g. informed,

473 thoughtful, insightful) and quality (e.g. sophisticated, intelligent, with depth) of

474 reflection undertaken. Reflection performances were judged through the products of

475 the coaches' reflection, and the coaches' displayed abilities as reflective practitioners:

476

477

478

479

480

481

\section{Interviews:}

Isla: Her reflections are broader; she is in a different system and culture that is evoking emotional responses... because the playing field that she is on is much broader when she comes to reflect, she is either being guided or is reflecting on different things now 
Janet: I would say he is very reflective, how conscious he is; we probably haven't gone there as much as we could have done.

Claire: He is in a very different place to some of them [other coaches on the program], he is very self-aware, astute and motivated, he uses; in a good way in my opinion, the whole experience of the programme. If something doesn't land for him, he shrugs and says, 'I don't see how I can apply it', anything that does land for him he really applies so I think that is very grown up demonstrating discernment.

The coach developers worked in terms of these ideas of the normal, making them concrete and substantial to shape and produce coaches as reflective coaches; hence, coach developers and coach education became a 'subtle and persuasive exercise of power' (Cushion, 2016; Gilbert, 2001, p. 200). Through the program, the coaches became enfolded in a discursive matrix of practices that constituted their 'learning needs' and helped define their path for self-development. This process was an effect of power because as data have shown, the coaches accepted the legitimacy of reflection, the need for reflection for their development, and were positioned as a particular kind of reflective coach. Importantly, power was not recognized as it was cloaked in what Usher and Edwards (2005) describe as the esoteric of objective knowledge (in the form of the coach developer), and because the coaches had internalized the humanistic discourse of personal empowerment. The apparently liberating and progressive use of reflective practice was a power-knowledge formation intertwining expertise and personal empowerment "displacing the need for active containment and overt oppression" (Usher \& Edwards, 2005, p. 401).

\section{Coach Developers: Confession, 'Empowerment', \& Reflection}

Dividing practices and examination include processes of confession and selfexamination, which act to constitute the self through revealing and marking what is 'known' (Usher, Bryant \& Johnston, 2001). Through reflective practice as self- 
examination, the coaches became what Usher et al. (2001) describe as active

512 accomplices in their own self-formation. Indeed, a key premise of the coach developers

513 and the purpose of reflection on the program was that existing knowledge needed to be

514 made visible. According to Foucault (1998), verbalization has become a central method

515 of knowing through which people make themselves visible to themselves and others.

516 Hence, through reflection, coaches contributed their knowledge through verbalization

517 - they confessed to others (Cotton, 2001; Fejes, 2011; Foucault, 1991). Indeed, the

518 program engendered an "obligation to confess" (Cotton, 2001; Foucault, 1991, p. 60;

519 Rolfe \& Gardner, 2006) and coach developers positioned the coaches as being in need

520 of confessing, acting to 'guide' and facilitate the confessional that brought forth the

521 coaches' personal histories:

\section{Interview:}

Poppy: It is about the coach talking about themselves or a situation they have found themselves in and about me asking questions and it is usually questions about both 'how's it been?', 'how's it felt?' 'what were you thinking, what are you thinking now, how do you want to move this forward?' Those types of questions.

\section{Fieldnotes}

Residential Workshop:

Will is leading a reconnect task, this includes a brief outline detailing what is to come over the next couple of days and relates to objectives and the value of the workshop.

Will: "Tomorrow is really around this collaborative learning and bringing you guys together and learning and sharing from each other, we are going to talk about developing some of our inquisitive skills in order to then notice what we hear, what feel and what we see in different environments in order to then ask good questions of each other about why we do what we do".

Interview:

Tim: Understanding what being a self-regulated learner is and the impact of that on reflection...[also] reflection 
through the guide of [one-to-one coach developer sessions], so trying to work with them to get the coach to be self-reliant - to reflect.

The coach developers, then, through reflection, acted to make knowledge visible and coaches disclosed themselves, sharing their personal histories for interpretation (Foucault, 1978). This meant knowledge could be objectified and made visible for scrutiny and assessment on the program. This process constituted the coaches as 'reflective practitioners' (Fejes, 2011, 2013; Gilbert, 2001) and is demonstrated here with data from a residential workshop:

Fieldnotes

\section{Residential Workshop:}

Will: I am going to ask you, if you are okay with it, is to just share one thing that you really want to bring to the group. I am going to ask Tim to record them, and then I think we have personal and collective responsibility to make sure that we bring those things. Shall we go around [the group], Stuart if you don't mind starting us off give us one example of something you really want to bring to the group, Tim will write them down.

Coach - Stuart: One of my many objectives I have discussed with my coach developer is to try different styles of leadership.

Will: That is great for us [coach developers] to know because as observers, or people who are capturing through our own notes, what we are seeing and hearing, we can start to feed that back in about what we notice.

Will highlights that the group have started to reconnect:

Will: "So, you have started to be very open, you have started to share as a group and share trust, in terms of what you will do with that information keep it within the four walls. But moving into how do we give feedback and have courageous conversations (workshop topics) I would like you to think about, in your head 'if I could change one thing about the group it would be...?' and give that feedback to the group. Have a think about what this group doesn't do well now and give them your feedback on that".

The group are given 30 seconds to think quietly. 
Will: "Ok, I am going to select one person to go and then they are going to select another person and they are going to go".

The coaches proceed to talk about their own weaknesses and things the group could do better. For example:

Coach - Richard: "I need to give the group more time".

Coach - Daniel: "We don't get feedback from each other enough".

Coach - Ben: "We don't communicate in between residentials enough".

Will responded positively "ok brilliant".

These data could be considered a typical discursive pattern from the program where the type of relationship between coach developer and the coaches meant that the process was driven by the developers while the coach's directed their confessions, in part, to 'real' and more powerful others (Foucault, 1998). Importantly, this type of discussion task was quintessential of the program and reified as coach led and learner centered. However, following Foucault, such practices were contrived situations that meant the possibility of surveillance was again heightened dramatically - "Tim to record them", "Tim will write them down". While certainly creating "different discursive possibilities" (Usher \& Edwards, 1994, p. 91), these tasks nonetheless served to simply reconfigure the regulation of the coaches who were subject to the "immediate scrutiny and surveillance of their peers" (Usher \& Edwards, 1994, p. 91), as well as the coach developers. This activity could be interpreted as performance theatre, a situation in which the coaches' actions were carefully watched by the coach developers as the "judges of normality" (Foucault, 1977, p. 304). Coach developers, in this example Will, monitored the extent to which the coaches were participating and contributing in a suitable manner, intervening to select coaches "to go", thus suggesting an unexpressed norm of what constituted a good discussion. 
610 coaches "if you are ok with it". This seems a perfunctory attempt to gain consent as

611 there was the unspoken knowledge that a lack of participation or a poorly articulated

612 coach contribution would be judged. In this case, the coach, Fran, is quick to correct

613 herself during a reflective discussion about a task:

614

615

616

617

618

619

620

621

622

623

624

625

626

628

629

630

631

632

633

634

635

636

637

638

639

640

641
Fieldnotes

Residential Workshop:

External Expert: What are your reflections from yesterday, what have you learned or taken away from last night's session?... Fran what about you? Have you taken anything away?

Coach - Fran: No

Laughter

Coach - Fran: Sorry I didn't mean for that to sound...the task got me thinking about communication.

Coaches' resistance or refusal to take part in such prescribed reflective strategies

would be seen as unacceptable and 'unprofessional' and the coach considered as the

'wrong kind of learner' or not being engaged, as these examples suggest:

Interviews:

Tim: The scenario (at the residential workshop) with George (coach); he was getting cheesed off with that guy - he saw it as 'I'm right he's wrong, I'd bin him off if I was working with him'. Not, 'why is he acting like this?', 'what am I doing to impact on that, what can I do to get the most out of him?'. He was just like; 'he's gone'. Now for me that is just showing a lack of willingness, or emotions not letting him, to reflect on why that is.

Tim: Richard (Coach) didn't engage whatsoever in the discussion and we didn't challenge him and say; 'you weren't comfortable were you, and that's why you [disengaged], you weren't happy were you?'.

Alan: Most people at this level are continual learners and you have to reflect to continue learning. 
643 intimately entwined with humanistic discourses of empowerment that emphasized the

644 need for the coaches to talk and know the truth about themselves. The premise being

645 that the more the coaches developed an 'authentic understanding of self', the more

646 'power' they would accrue and be able to learn according to their own perceived needs.

647 At face value, such learner centeredness can be empowering, creating what Foucault

648 (1998) calls 'active' knowing subjects. Indeed, coach developers asked questions about

649 what had happened, how the coach was feeling, their thoughts and beliefs during and

650 after the coaching experience, and their ideas for future action. Such questions

651 demonstrate the latency principle of confession (Mills \& Denison, 2018), as they

652 promoted 'looking into yourself' and 'finding your true self' to enable the emergence

653 of self-knowledge (Usher \& Edwards, 1994). For example:

654

655

656

657

658

659

660

661

662

663

664

665

666

667

668

669

670

\section{Interviews:}

Isla: 'I am wondering why, I am wondering what went on for you there, I am interested in what you're feeling now as you talk to me about this, what is going on for you now'.

Rebecca: Why is possibly a bit critical, the 'why' is the most critical of all beginnings of questions.

Interviewer: So, how would you?

Rebecca: So, 'I notice...' and 'I wonder...' 'what that's about...' If you think, kids ask the most 'why' questions... 'why' is a penetrating, quite a provocative question...Well you usually ask a 'why' question because in your world you don't get that - you know morally, educationally, spiritually, whatever it is, 'why did you do it that way?' You're really curious because it is not the way you would have done it.

At the same time, however, issues of power were not recognized by coach developers or coaches because reflection was viewed as a neutral process that could enable effective action while remaining disconnected from power (cf. Usher \& Edwards, 

1994). Indeed, the coach developers were at pains to distance themselves from these issues and viewed the process as entirely neutral, for example:

\section{Interviews:}

Isla: ...reflect on what is going on for you...you're not giving them your solution you are just reflecting on it for yourself.... So that then takes away judgement, so 'this is what is happening for me when I am listening to your problem'.

Rebecca: If I apply a lens to myself around being better it would be an inquiry lens, full stop no judgment... If I speak to people about self-inquiry [instead of critical inquiry] they are much more open to what might happen next...because who is the judge of right and wrong really?

However, reflection on the program functioned as regulation through self-regulation and was disciplining through self-discipline, a process that may have felt and seemed empowering to the participants, but was within a regime where power was never absent. The 'self-reflective coach' does not overcome power relations; instead the individual governs themselves within relations of power (Nicoll \& Fejes, 2008). For as Denison et al. (2015) describe, Foucault (1995) argues that in regimes [programs] where individuals [coaches] believe they need to be 'empowered' by another [coach developer] to learn and know more about themselves they are actually becoming 'disempowered' in the very process of 'self-empowerment'. That is, "as individual subjects, there is no transcendental position from which we can become 'empowered'; there are only particular discursive positions within power/knowledge formations that we can occupy (Edwards \& Usher, 1994)” (Denison et al., 2015, p. 7). Hence, empowering intent became submerged in the authority and authoritative actions of the coach developer as confessor acting to bring out more and more dimensions of the coaches, expanding the space for intervention and 'development', but also space for the exercise of power. Thus, making the coaches increasingly visible to normalizing 
judgements about the processes of reflection, as well as the quality of the knowledge

701 generated, and reinforcing surveillance and coach self-surveillance. In response,

702 coaches had little choice other than to 'correct' their thoughts or behaviors in line with

703 the developers' therapy (Mills \& Denison, 2018), as Fran demonstrated earlier "sorry I

704 didn't mean for that to sound...the task got me thinking about communication”. Micro

705 techniques related to reflection were used, such as debriefing sessions, journal writing,

706 and shared reflective narratives with the group where coaches had to write and talk

707 about their activity. Despite the coach developers' intentions, this was not a liberating,

708 critical process, but acted to produce outcomes that constrained the coaches in what

709 might be considered valid knowledge. In this example, coach developers explained that

710 'the content will be driven by you [coaches] as a cohort', but then guided coaches to

711 coach developer and program topics, such as managing meetings:

712

713

714

715

716

717

718

719

720

721

722

723

724

725

726

727

728

729
Fieldnotes

Residential Workshop:

Coaches picture stories reflection task

Coaches talk through 'where they are now'.

Discussion/Questions following Fran's presentation:

Coach - Daniel: Where do you get your energy from?

Coach - Fran: Championships I like that bit, I am 'do-er', I am not keen on the meetings...I was coaching and leading all at once I learned that doesn't work and it is hard to not to 'tell' [people what to do]. I am highly sceptical, and I don't trust easy, so it's a bit of a dilemma for me because I have to give responsibility. I didn't realise but apparently, I am [sceptical], so now I know how, I know my role, so I had a problem.

Will: So, you are brilliant at championships and that is where you get your energy, if you can run brilliant meetings, something [External Expert] talked about, what are you thinking about that? 
In addition, these micro techniques were a further mechanism that allowed coaches'

731 thinking to become visible to others, and once in the public sphere could be subjected 732 to interpretation and judgment (Cotton, 2001). Importantly, surveillance requires a 733 degree of visibility to be maintained (Gilbert, 2001); individuals must be aware and 734 committed to act upon its effects, as was the case on the program:

\section{Interviews:}

Coach - Ben: I think that we need a way where when you reflect there is some stuff that you could share rather than be it like 'that's mine I don't want to share it with people'.

Coach - Daniel: I find reflecting in a group quite good... actually talking that [coaching issues] through as a group is probably the most powerful...I mean a lot of it is about self and developing you, but I get so much from the other coaches. The knowledge of how people do various things in their sport I find really really useful.

Coach - Harry: The more you work with someone like a coach developer, who asks you the right questions...you naturally start to ask the right questions yourself...in the last 12 months...the questions I think to myself about are at a higher level.

Through inciting the self to act upon the self through reflective practice, the individual coaches became self-managing. This ensured that between contact with the developers and program residentials, the individual coach could confront their 'weaknesses' and act upon them. Coaches were thus guided to recognize the 'limitations' of their practice and through reflection a modification of behavior was expected (Cassidy et al., 2009; Fejes, 2011; Gilbert \& Côté, 2013). Indeed, behavior change was the desire of all involved and the objectives and purpose of the coach education program:

\section{Fieldnotes}

\section{Residential Workshop:}

Will addressing the coaches: "What we are ultimately trying to get to here is behavior change for you and your athletes or players" 
Interview:

Will: We need to continue to focus on how they [coaches] have made sense of what they have just heard and bring that to life in their own environment so that they have reference point and they also have something tangible where 'I can see how I am going to apply this in my environment and this is worthwhile and therefore I am going to actively try and change me or an athlete's behavior in order to get a different outcome'

Therefore, through reflection, coach subjectivity was not determined but became elicited, fostered, and shaped (Fejes, 2008, 2013; Foucault, 2007) in a situation of 'freedom' (Fejes, 2013), where the individual coach made choices based on reflection (i.e. governed the self).

\section{Implications - developing 'counter-practice'}

Foucault (1991a) argued that analysis should not generate advice, guidelines, or instruction as to what is to be done, seeking instead to unsettle what is taken-forgranted, rather than produce recipes for action. Therefore, rather than lead to suggestions for improvement in policy and practice or offer solutions to problems, our idea here was to make visible to coach education 'policy makers' and coach developers, and coaches 'on the ground', a different, destabilized and problematised version of reflection. The purpose, in this case, was to destabilise things about reflection that are currently and ordinarily taken-for-granted; to introduce awkwardness into the fabric of our experiences of reflection by making coach developer and coach narratives 'stutter' (Nicoll \& Fejes, 2008; Rose, 1999).

This approach is in direct contrast to a significant body of research that presents and perpetuates particular discourses of reflection that currently fail to recognize relations of power - power that is not acknowledged in everyday policy making and practices of coach developers, coach education, or research into it. These discourses (as the data in this case suggest) position reflection as an individual, asocial, ahistorical 
process within a "dominant psychologism and...humanistic discourse" (Cushion, 2016,

792 p. 2). Such discourses have become reified and confirmed through repeated social 793 practices; embedded in coaching to assume what Foucault (1980a) calls a status of truth 794 (e.g. Huntley et al., 2014; Knowles et al., 2001; Taylor et al., 2015) (Cushion, 2016). 795 The outcome of which has meant that reflection in coaching has retained a 'seductive 796 appeal' that has often deflected critical thought (Fendler, 2003, p. 22).

797 While the developers and coaches positioned reflection as free from power, 798 Foucault helps 'read' reflection alternatively as a mechanism of power where 799 individuals (shaping subjectivity) are governed and govern themselves within relations 800 of power. Thus, the research enables us to see how generalized narrations of reflection 801 as power 'neutral' and 'empowering' can be misguided. Moreover, the research shows 802 that attempts by coach developers, through the coach education program, to be 'critical' 803 and 'learner centred' are embroiled with intrinsic relations of power, and the stated 804 intention of being 'neutral' and 'empowering' may in fact exacerbate rather than 805 ameliorate the workings of power (cf. Nicoll \& Fejes, 2008). An implication therefore 806 lies in not accepting passively 'what we do', but as Foucault (1980) suggests, 807 emancipating local discursivities and subjugated knowledges to "render them...capable 808 of opposition and of struggle against hegemonic discourses" (p.85). In other words, to 809 consider critically the discursive complexities of reflection and reflective practice and 810 go some way to challenge notions of reflection portrayed repeatedly in coaching as an 811 unbiased and objective process that occurs in a politically neutral environment 812 (Cushion, 2016).

813 By focusing on the how and what of power, we have been able to take a critical 814 attitude towards, and to question present understandings of, coach developer practice 815 and reflection by making visible how power operates. Revealing, what Johns (1999) 
describes as, a shadowy world of surveillance where reflection practices extract and

817 objectify confession and subject coaches to the powerful gaze of others, thus ensuring 818 coach conformity to a received ideal image of coaching and practice, as well as of 819 reflection itself. Importantly, and as Foucault reminds us, such “critique doesn't have 820 to be the premise of deduction which concludes: this then is what needs to be done. It 821 should be an instrument for those who fight, those who resist and refuse what is" 822 (1991a, p. 84). In other words, this research contributes to a 'practical critique' in the 823 form of transgression (Foucault, 1991b, p.45), or what Biesta (1998b, 2008) has called 824 counter-practice. Thinking in terms of counter-practice helps resist the temptation to 825 'fix' policy or practice. Instead, the critical work of counter-practice consists of 826 showing that the 'way things are' is only one (limited) possibility (Biesta, 2008). This 827 tiny, but significant, step is crucial as it opens up the possibility for coaches and coach 828 developers "of no longer being, doing, or thinking what we are, do, or think" (Foucault, 829 1991b, p. 46).

830 Counter-practice helps show that coach developers can play a crucial role in 831 helping reflection fulfil its developmental and empowering potential. Acting as a 832 'guide', developers can help coaches to ask deep questions about self, relating the self833 to-the-self and rooting out taken-for-granted or 'natural' conflict and contradiction 834 (Johns, 1999). This could enable coaches to see the constraints on achieving desirable 835 practice within particular situations (Denison et al., 2015). Such an approach acts in 836 opposition to a process of surveillance that currently considers self in comparison with 837 a normalized other and where contradictions and conflict are rationalized against a 838 norm. Hence counter-practice shows that the differences between such practices can be 839 identified and empower coach developers. However, this does not position coach 840 developers 'outside' power, or indeed offer a 'better' way. Rather, it supports them to 
see the culture and power relations they are in and prepares them to work within them.

842 This provides opportunities for different ways of doing and being and can provide

843 support for coach developers and coaches resisting or refusing particular subjectivities

844 or subject positions (and also adopting particular subjectivities or subject positions).

845 This requires judgement and as Fendler (2003) argues to maintain a "skeptical and 846 critical attitude about what we do" and examine the role of reflection to avoid it

847 becoming a "normalizing technology that reproduces assumptions" (p. 23). Therefore, 848 whether coaches and coach educators accept particular subjectivities or subject 849 positions is, at the end of the day, up to them. This research therefore encourages coach 850 developers to not only consider what they do to construct reflection's meaning and 851 support reflective practice and why, but also what this meaning and what their practice 852 does to coaches and relations of power (Foucault, 1965). Coach developers cannot be 853 an 'enlightened guide' (Rolfe \& Gardner, 2006, p. 595) if they themselves are not 854 enlightened and this research helps make visible that there is at least some choice.

\section{Conclusion}

856 The purpose of this paper was to consider critically the discursive complexities of 857 reflection and reflective practice in high performance coach developers' support. 858 Foucauldian analysis problematized the seemingly unproblematic, shining a light on 859 power relations omnipresent in reflective practice support. Similarly to Mills and 860 Denison $(2013 ; 2018)$, the research did not intend to be critical of the methods coach 861 developers employed, but rather the operations of power that formed methods 862 representing reflection. Indeed, analysis highlighted the unintended consequences of 863 the coach developers' well-intended actions. Practically, the coach developers 864 supported reflection and reflective practice through questioning, observing, and 865 providing feedback, but this also fostered in the coaches an 'obligation-to-confess'. 
Reflective practice was underpinned by a humanistic discourse, that dominated both

867 the one-to-one sessions and coach education workshops. Together this approach to 868 reflection was viewed unproblematically as 'good' for coaches.

869 However, coach developers as reflective or 'critical friends' served to reinforce 870 practitioners' self-surveillance and arguably contributed to the construction of docile 871 and competent workers (Foucault, 1977). Importantly, this was the opposite of the 872 coach developers' and program's intentions that focused on supporting critical 873 thinking, innovation, and creativity. Instead, reflection in this form constructed 874 coaches, unintentionally, as people who disclosed and affirmed their identity in terms 875 of categories reflective of existing assumptions about coach education for high 876 performance coaching and coaches, such as 'highly-practical', 'learning from other 877 coaches' and 'self-regulated learners'. This could authenticate and promote certain 878 ways of thinking about and being a coach, while potentially dismissing others and 879 possibilities for thinking outside existing categories, as coaches are silenced by the 880 dominant discourse (Cushion, 2016; Cushion \& Partington, 2014; Fendler, 2003). Importantly, this exercise of power became subtle and persuasive through

882 humanistic discourses of the developers that fostered notions of 'empowerment'.

883 Therefore, power had not been removed, but reconfigured, and resulted in a growing 884 tension between the coach developer's role to support, but also to judge. These findings 885 suggested that coach developers cannot be detached from power as all negotiations, 886 including those connected to reflection, are always within systems of domination 887 (Foucault, 1982). It is therefore dangerous for power to be overlooked.

\section{$888 \quad$ References}

889 Biesta, G. (1998b). "Say you want a revolution..." Suggestions for the impossible 890 future of critical pedagogy. Educational Theory, 48, p. 499-510.

891 Biesta G. (2008). Encountering Foucault in lifelong learning. In Fejes, A. \& Nicholl, 
K. Foucault and Lifelong Learning: Governing the Subject. p. 193- 205. London: Routledge.

Braun, V., \& Clarke, V. (2006). Using thematic analysis in psychology. Qualitative Research in Psychology. 3, p. 77-101.

Braun, V., \& Clarke, V. (2013). Successful qualitative research: A practical guide for beginners. London: Sage.

Brookfield, S. (2009) The concept of critical reflection: promises and contradictions. European Journal of Social Work. 12, (3), p. 293-304, DOI:10.1080/13691450902945215

Bryman, A. (2016). Social Research Methods. ( $5^{\text {th }}$ Edition). Oxford: Oxford University Press.

Cassidy, T., Potrac, P., \& McKenzie, A. (2006) Evaluating and Reflecting upon a Coach Education Initiative: The CoDe of Rugby. The Sport Psychologist. 20. (2), p. 145-161.

Cassidy, T., Jones, R., and Potrac, P. (2009). Understanding Sports Coaching: The social, cultural and pedagogical foundations of coaching practice. $\left(2^{\text {nd }}\right.$ Edition). London: Routledge.

Clarke, V., \& Braun, V. (2017) Thematic analysis. The Journal of Positive Psychology. 12 (3), p. 297-298, DOI: 10.1080/17439760.2016.1262613

Cole, C., Giardina, M., \& Andrews, D. (2004). Michel Foucault: Studies of Power and Sport. In Giulianotti, R. Sport and Modern Social Theorists. (p. 207-223). London. Palgrave Macmillan ltd.

Cotton, A. (2001). Private thoughts in public spheres: Issues in reflection and reflective practices in nursing. Journal of Advanced Nursing, 36. (4), p. 512519.

Cropley, B., \& Hanton, S. (2011). The role of reflective practice in applied sport psychology: Contemporary issues for professional practice. In Hanton, S. \& Mellalieu, S. (Eds.), Professional practice in sport psychology: A review. p. 307-336. London: Routledge.

Cropley, B., Miles, A., \& Peel, J. (2012). Reflective practice: Value of, issues, and developments within sports coaching. Sports Coach UK Original Research.

Culver, D., \& Trudel, P. (2006). Cultivating coaches' communities of practice. In R. L. Jones (Eds.), The sports coach as educator: Reconceptualising sports coaching. (p.113-127). London: Routledge.

Cushion, C. (2006). Mentoring: Harnessing the power of experience. In Jones, R. (Ed.), The sports coach as educator: Re-conceptualising sports coaching ( $\mathrm{p}$. 128-144). London: Routledge.

Cushion, C. (2014). Ethnography. In Nelson, L., Groom, R., and Potrac, P. [Eds] Research Methods in Sports Coaching. (p. 171-180). London: Routledge.

Cushion, C. (2016). Reflection and reflective practice discourses in coaching: a critical analysis. Sport, Education and Society. 3322., p. 1-13. 
Cushion, C., Ford, P., \& Williams, M. (2012). Coach behaviours and practice structures in youth soccer: Implication for talent development. Journal of Sport Sciences. 30. (15), p 1631-1641.

Cushion, C., Griffiths, M., \& Armour, K. (2018). Professional coach educators insitu: a social analysis of practice. Sport, Education and Society. DOI: 10.1080/13573322.2017.1411795.

Cushion, C., \& Jones, R. (2014). A Bourdieusian analysis of cultural reproduction: socialisation and the 'hidden curriculum' in professional football. Sport, Education \& Society, 19. (3), p. 276-298.

Denison, J. (2007). Social theory for coaches: A Foucauldian reading of one athlete's poor performance. International Journal of Sport Science and Coaching. 2, p. 369-383.

Denison, J. (2010). Planning, practice and performance: the discursive construction of coaches' knowledge. Sport, Education and Society. 15, p. 161-478.

Denison, J., Mills, J., \& Konoval, T. (2015). Sports' disciplinary legacy and the challenge of "coaching differently." Sport, Education and Society, 3322 (August 2015), p. 1-12. https://doi.org/10.1080/13573322.2015.1061986

Douglas, K., \& Carless, D. (2008). Using stories in coach education. International Journal of Sports Science and Coaching. 3, (1), 33-49.

Fejes, A. (2008). Governing nursing through reflection: A discourse analysis of reflective practices. Journal of Advanced Nursing, 64, (3), p. 243-250.

Fejes, A. (2011). Confession, in-service training and reflective practices. British Educational Research Journal. 37. (5), p. 797-812.

Fejes, A. (2013). Foucault, confession and reflective practices. In M. Murphy (Eds.), Social Theory and Education Research (p. 52-66). London: Routledge.

Fendler, L. (2003). Teacher reflection in a hall of mirrors: Historical influences and political reverberations. Educational Researcher, 32. (3), p. 16-25.

Foucault, M. (1965). Madness and Civilization; a history of insanity in the age of reason. New York: Vintage books.

Foucault, M. (1972) The Archaeology of Knowledge and The Discourse on Language. New York: Pantheon Books.

Foucault, M. (1975). 'Interview on the prison: the book and its method'. In Faubion, J. (ed). (2002). Michel Foucault: Power: essential works of Foucault 19541984, volume 3. Penguin Books.

Foucault, M. (1977). Discipline and punish: the birth of the prison. London: Penguin.

Foucault, M. (1980). Two lectures. In Gordon, C. (Ed.), Power/knowledge: Selected Interviews and other writings 1972-1977: Michel Foucault. (p. 78-108). Sussex: The Harvester Press.

Foucault, M. (1982). Technologies of self. In P. Rainbow (Series Ed. \& Vol Ed.) The essential works of Michel Foucault 1954- 1984: Vol 2. Ethics: Subjectivity and truth. (p. 223-251). New York, NY: The New Press.

Foucault, M. (1991). Truth and power. In Rainbow, P. (Eds.), The Foucault reader. (pp. 51-75). London: Penguin.

Foucault, M. (1991a). Questions of method. In G.Burchell, C.Gordon, \& P. Miller 
(Eds.). The Foucault Effect. Studies in Governmentality. Chicago: The University of Chicago Press.

Foucault, M. (1991b). What is Enlightenment? In Rainbow, P. (Eds.), The Foucault reader. (pp. 32-50). London: Penguin.

Foucault, M. (1996). Talk show. In S. Lotringer (Eds.), Foucault live: Interviews, 1961-1984 (pp. 133-145). New York, NY.

Foucault, M. (1998). The Will to Knowledge: The History of Sexuality: Volume One. London: Penguin Books.

Foucault, M. (2007). Security, territory, population: Lectures at college de France 1977-1978. Basingstoke: Palgrave-MacMillan.

Gallimore, R., Gilbert, W., \& Nater, S. (2014). Reflective practice and ongoing learning: A coach's 10-year journey. Reflective Practice: International and Multidisciplinary Perspectives, (15), p. 268-288.

Gearity, B. \& Mills, J. (2013). Discipline and Punish and the Weight Room. Sport Coaching Review. 1. (2), p. 124-134.

Gilbert, T. (2001). Reflective practice and clinical supervision: Meticulous rituals to the confessional. Journal of Advanced Nursing, 36. (2), p. 199-205.

Gilbert, W., \& Côté, J. (2013). Defining coaching effectiveness: A focus on coaches' knowledge. In Potrac, P., Gilbert, W., \& Denison, J. (Eds.), Routledge handbook of sports coaching (p. 147-159). London: Routledge.

Gilbert, W., \& Trudel, P. (2001). Learning to coach through experience: Reflection in model youth sport coaches. Journal of Teaching in Physical Education. 21, p. $16-34$.

Gilbert, W., \& Trudel, P. (2006). The coach as a reflective practitioner. In Jones R (Ed.), The sports coach as educator: reconceptualising sports coaching ( $\mathrm{p}$. 114-127). London: Routledge.

Hammersley, M., \& Atkinson, P. (2007). Ethnography: Principles in practice. $\left[3^{\text {rd }}\right.$ ed.] Abingdon: Routledge.

Huntley, E., Cropley, B., Gilbourne, D., Sparkes, A., \& Knowles, Z. (2014). Reflecting back and forwards: An evaluation of peer reviewed reflective practice research in sport. Reflective Practice, 15. (6), (p. 863-876).

Irwin, G., Hanton, S., \& Kerwin, D. G. (2004). Reflective practice and the origins of elite coaching knowledge. Reflective Practice. 5, (3), 425-442.

Johns, C. (1999). Reflection as Empowerment? Nursing Inquiry. 6, p. 241-249.

Kidman, L. (2005). Athlete-centred coaching: Developing inspired and inspiring people. Christchurch: IPC Print Resources.

Knowles, Z., Borrie, A., \& Telfer, H. (2005). Toward the reflective sports coach: Issues of context, education and application. Ergonomics. 48. (11-14), p. 1711-1720.

Knowles, Z., Gilbourne, D., Borrie, A., \& Nevill, A. (2001). Developing the Reflective Sports Coach: A study exploring the processes of reflective practice within a higher education coaching programme. Reflective Practice. 2, p. 185207. 
Knowles, Z., Tyler, G., Gilbourne, D., \& Eubank, M. (2006). Reflecting on reflection: Exploring the practice of sports coaching graduates. Reflective Practice. 7.(2), p. 163-179.

Mills, J. \& Denison, J. (2013). Coach Foucault: Problematizing endurance running coaches' running practices. Sport Coaching Review. 2. (2), p. 136-150.

Mills, J. \& Denison, J. (2018). How power moves: A Foucauldian analysis of (in)effective coaching. International Review for the Sociology of Sport. 53. (3), p 296-312.

Nelson, L. J., \& Cushion, C. J. (2006). Reflection in Coach Education: The Case of the National Governing Body Coaching Certificate. Sport Psychologist. 174183.

Nicoll, K. \& Fejes, A. (2008). Mobilizing Foucault in Studies of Lifelong Learning. In Fejes, A. \& Nicholl, K. Foucault and Lifelong Learning: Governing the Subject (p. 1-18). London: Routledge.

Orlie, M. (1997). Living Ethically, Acting Politically. Ithaca, NY. Cornell University Press.

Patton, M. (2002). Qualitative Evaluation and Research Methods: Third Edition. Thousand Oaks, CA: Sage.

Richards, P., Mascarenhas, R. D., \& Collins, D. (2009). Implementing reflective practice approaches with elite team athletes: Parameters of success. Reflective Practice. 10, (3), 353-363.

Rogers, C. (1983). Freedom to Learn for the eighties. CE Merrill, Columbus, Ohio.

Rolfe, G., \& Gardner, L. (2006). 'Do not ask who I am ...': Confession, emancipation and (self)-management through reflection. Journal of Nursing Management, 14, (8), p. 593-600.

Rose, N. (1999). Powers of Freedom: Reframing Political Thought. Cambridge: Cambridge University Press.

Smith, B. \& Sparkes, A. (2017). 'Interviews: qualitative interviewing in the sport and exercise sciences. In Smith, B., \& Sparkes, A. [Eds]. Routledge Handbook of Qualitative Research in Sport and Exercise, (p. 103-123). London: Routledge.

Taylor, S., Werthner, P., Culver, D., \& Callary, B. (2015). The importance of reflection for coaches in parasport. Reflective Practice, 16, (2), p. 269-284.

Trudel, P., Culver, D., \& Werthner, P. (2013). Looking at Coach Development from the Coach-Learner's Perspective: Consideration for Coach Development Administrators. In Potrac, P, Gilbert, W., \& Denison, J. (Eds.), Routledge Handbook of Sports Coaching p. 375-387. London: Routledge.

Trudel, P., Rodrigue, F., \& Gilbert, W. (2016). The journey from competent to innovator: Using appreciative inquiry to enhance high performance coaching. AI Practitioner. 18. (2). p. 40-46. doi.org/10.12781/978-1-907549-27-4-5

Usher, R., \& Edwards, R. (1994). Postmodernism and education. London: Routledge.

Usher, R., \& Edwards, R. (2005). Subjects, networks and positions: Thinking educational guidance differently. British Journal of Guidance \& Counselling. 33, (3), p. 397-410, DOI: 10.1080/03069880500179640. 
1063 Usher, R., Bryant, I., \& Johnston, R. (2001). Adult Education and the Postmodern $1064 \quad$ Challenge: Learning Beyond the Limits. London: Routledge.

1065 Webster, L., \& Mertova, P. (2007). Using narrative inquiry as a research method: An 1066 introduction to using critical event narrative analysis in research on learning 1067 and teaching. London: Routledge. 